\title{
Customer Services: A Case Study of Cellular Phone Companies in Pakistan
}

\author{
Rizwan A. Bhutto and Azra Maqsood \\ SZABIST \\ Karachi, Pakistan
}

\begin{abstract}
Customer Service is a highly demanding and challenging job in service sector. It is most difficult and greatly intricate but is inevitable for survival in any competitive market. Better-informed customers are more discerning customers; they want it all. Nothing less than high-quality, fully featured products at reasonable prices are needed to satisfy them. As a consequence, they are in a position to demand service, customized products and personal attention. Deregulation of services, growing competition, fluctuations in demand, and the application of new technologies are presenting a considerable challenge to service companies. The mastery of customer service can mean the difference between success and failure. The corporate trend of raising customer service is a business necessity. Experts believe that customers are more willing to forgive a product failure than a service failure by a ratio of 5 to 1. The service-oriented transformation is the successor to classic business transformation initiatives. Service-oriented transformation represents new methodologies and approaches that incorporate new technology trends such as service-oriented architecture, enterprise service bus, and model-driven architecture.
\end{abstract}

Keywords: Service Sector, Customized products, Deregulation, Service-oriented transformation, Enterprise Service Bus, Model-driven Architecture.

\section{INTRODUCTION}

Customers today are well-informed and dynamic. At the same time the competition is fierce, and customers have more options than ever, a tough combination for smaller companies trying to gain market share. Marketing services and service companies within the same industry are becoming increasingly similar; in such circumstances it is inevitable for business companies to overcome the challenges through efficient customer services. To survive, intelligent organizations continually learn from customers, competitors, and successful practitioners everywhere in the marketplace. These organizations need to use a number of customer service strategies to thrive in highly competitive and demanding economy. A paradigm shift is taking place in services marketing. The shift is from a transaction-oriented "marketing mix" view of exchanges to a relationship marketing view. The focus is turned away from how to acquire new customers to how to develop, enhance, maintain and sustain relationships through conceding information and facilitating customers through state of the art effective communication channels. The strength of a relationship is affected both by the degree of commitment between the customer and service provider and the strength of the bonds between them.

Customer service has become such an important competitive differentiator that it is no longer solely the responsibility of a small group of individuals staffing a complaint desk. Customer service is every employee's responsibility, and it should be a proactive rather than a reactive strategy. Excellent service wins and keeps customers.

\subsection{FOCAL AREAS}

- Service Sector: Services are also often difficult to separate from goods with which they may be associated in varying degrees [1]. In its simplest form "service" is known as the non-material equivalent of a good in economics and marketing. Important in their own right, they also serve as crucial inputs into the production of most goods. Service provision has been defined as an economic activity that does not result in ownership, and this is what differentiates it from providing physical goods. It is claimed to be a process that creates benefits by facilitating a change in customers, a change in their physical possessions, or a change in their intangible assets. In a narrower sense, service refers to quality of customer service: the measured appropriateness of assistance and support provided to a customer.

o Growth of Service Sector: The expansion of the services sector has always been seen as a necessary concomitant of economic growth, to the point where it is often listed as one of the indicators of the economic development process. A marked increase in the GDP share of the service sector has been one of the striking features of the world growth patterns in recent years. Initially agriculture was considered as dominant factor in economy building. With the time agriculture loses its primacy, giving way first to rise in the industrial sector, then to a rise in the service sector. This has changed the paradigm as incomes continue to rise, people's needs become less "material" and they begin to demand more services. Service sector growth has thus become a major factor for sustainable development.

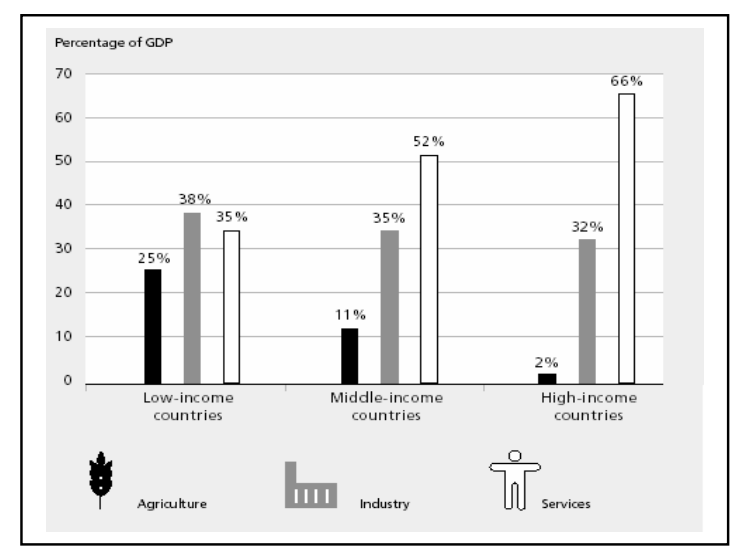

Sectoral Structure of World Economies (Source: World Bank Statistics Book) 
- Telecom Services: Commitments in telecom services were first made during the Uruguay Round (1986-1994), mostly in value-added services. In extended negotiations thereafter (1994-1997), members negotiated on basic telecommunications services, with importance to increasing shareholder value with due emphasis to costing as well as service level agreements.

In Pakistan during last three years, massive growth has been registered in the telecom sector through fixed-line deregulation, and mobile/cellular policies. These policies have gone a long way in achieving their objectives in terms of infrastructure development; increase in investment; the range of quality and choice of services for customers; extension of telecom services to remote areas; and encouragement of fair competition among operators. The success of the policies was also reflected in the sector growth statistics which showed US \$ 1.13 billion revenue generation from auction of frequency spectrum, \$ 495 million Foreign Direct Investment (FDI) in telecom area during 2004-05, with an increased growth in fixed telephony [2].

\subsection{IMPORTANCE OF CUSTOMER SERVICE}

Deregulation of services, growing competition, fluctuations in demand, and the application of new technologies are presenting a considerable challenge to service companies. The service providing companies, therefore, need new approaches to address the challenge. Delivering customer service begins with understanding customers' needs. Customer service is bi-facet subject and can be judged from customer's perspective, based on theory from consumer behavior and cognitive psychology. The customer core expectations lie in areas, as identified by Martha Rogers, a specialist in customer service management and an Inc. Web Awards 2000 judge. In her article, Rogers offer these pointers [3]:

- Individual identification of customers; customer need special attention and love to be identified by service provider every time h/she comes in, through any channel.

-Determination of customer value and treatment accordingly; like for example corporate customer is of greater value than an ordinary customer is, and therefore customer service department makes different offers and spend more resources on the segment.

- The close interaction with customers; it's a reciprocal learning process for both the customer and service provider through exchange of information and care. The company has greater responsibility and needs to be proactive by making use of innovative processes and by offering customized/ personalized information.

In a competitive environment, however, satisfaction may not be enough. To stay in business, firms must be at least as satisfactory as their competitors. Moreover, firms that aim to gain profitable growth must increase the number of their customers, while reducing the cost of customer acquisition. Unfortunately most companies treat their customers like peas in a pod. Customer service is one of the most important levers of profitability, but one of the least understood. Business entities can improve customer service and lower costs at the same time, but this requires reexamining some important assumptions about how customer service is defined, measured, and managed.

\subsubsection{Latest Customer Service Approach}

Customer service is now more than a conventional activity and is deeply penetrated in all business processes. Services are a special kind of product. They may require special understanding and special marketing efforts. The services marketing mix is an extension of the 4Ps framework. The essential elements of product, promotion, price and place remain but three additional variables - people, physical evidence and process - are included to make it a 7Ps mix. The need for the extension is due to the high degree of direct contact between the service providers and the customers. According to consumer behavior study, it is the behavior that consumers display in seeking, purchasing, using, evaluating, and disposing of products and services that they expect will satisfy their needs. The individual customers make decisions to spend their available resources (money, time, effort) on consumption-related items. These decisions results from mental, physical, and observable actions [4].

\subsubsection{Customer Service as a Competitive Tool}

The mastery of customer service can mean the difference between success and failure. The corporate trend of raising customer service is a business necessity. According to services experts, customers are more willing to forgive a product failure than a service failure by a ratio of 5 to 1 . If customer retention is important, then improving customer service must be the tactic. Today's customers are increasingly sophisticated, educated, confident, and informed. They have high expectations of the service they want to receive. They want greater choice and will not be 'sold to' or manipulated. Over recent years organizations have placed increasing emphasis on customer service as a means of gaining competitive advantage. The purpose of competitive strategy is to achieve a sustainable competitive advantage (SCA) and thereby enhance a business's performance. There is a complete paradigm shift in customer service from what it was 20 years ago; companies now offer wide selection of value-for-money products backed by a high quality service. The traditional way of dealing customers has taken $360^{\circ}$ turn by offering a friendly, efficient service 24 hours a day, 365 days a year. In 1954 Peter Drucker wrote in The Practice of Management: 'There is only one valid definition of business purpose: to create a customer'. He said that an organization's ability to remain in business is a function of its competitiveness and its ability to win customers from the competition. The customer is the foundation of the business and keeps it in existence [5].

The customer service organizations at the cellular service providing companies are setting new standards: using optimal processes and support from modern information technology, the mobile telephone operators seeks to work most efficiently. The service providing companies now rise to competitive heights, and focus on service concept, 
the composition of the package, and service delivery systems. They subsequently create and enhance the strategic human resource development. An important and essential difference between customers buying a product and customers buying a service is that the latter will seldom be content to study the service concept and benefits alone; they will also be interesting in evaluating the service delivery system. The service is intangible and difficult to evaluate, but the potential customer can discover clues by assessing the service delivery system. Equipment, premises, financial resources, and particularly human resource will all be closely scrutinized and subjected to tests [6]. The customers who are skillful buyers will find many chances of discovering whether such norms are really applied, or they will create situations to test them out.

\subsection{CELLULAR PHONE SERVICE SECTOR IN PAKISTAN}

The telecommunication sector in Pakistan has registered a robust growth beginning 2002. During last three years, massive growth has been registered in its telecom sector through fixed-line deregulation, and mobile cellular policies which have gone a long way in achieving their objectives in terms of infrastructure development, increase in investment and the range of quality and choice of services for customers, extension of telecom services to remote areas and encouragement of fair competition among operators. It is expected that the number of mobile phone subscribers would touch the 50 million mark during next two to three years. The tendency towards cellular phone is tremendous as every month around 1.5 million consumers are joining the ever-expanding mobile subscribers' base. In December 2005, 2.02 million people subscribed to the mobile phone service which unprecedented. Pakistan is likely to attract up to US \$ 4 billion investment in the telecom sector in the next three to four years given the tremendous scope for growth.

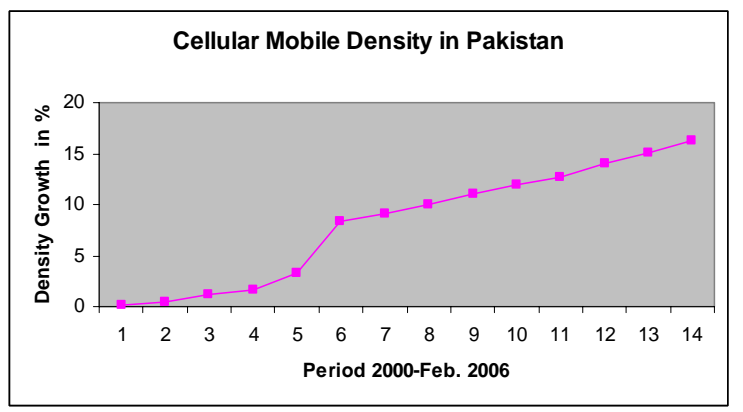

Growth Graph of Cellula/Mobile Phone Subscription in Pakistan

(Source: Pakistan Telecommunications Authority (PTA)

The mobile phone operators - Mobilink, Ufone, Telenor, Warid, Paktel and Instaphone are developing infrastructure to take lead in most severe competitive environment. The entire cellular telecom sector employs some 30,00035,000 workforces directly and indirectly, which is expected to increase in future.
In addition, the mobile phone may be viewed as one of the primary enabler of creating an IT culture in the country. Mobile phones today are no more mere voice carrying devices but are being used increasingly as data carrier, Internet tool, etc. The mobile phones are used today to send and receive data, picture, information, net surfing, and ordering merchandise from a location across the globe, and executing a business deal in matter of seconds. The increased used of mobile phones thus translates into increasing the share of Information Communication Technologies (ICTs) which is part of the services sector.

\subsection{MEASURING CUSTOMER SERVICES}

Customer satisfaction can be measured at many different levels. Usually, when we think of customer satisfaction, we think of a general feeling: Is the customer happy or unhappy with the service provider? However, we might also be interested in the customer's satisfaction with a specific interaction with the company ---- a phone call, a billing statement, or a visit to the company's Web site etc. Since customer services have diverse standards, it varies from subject to subject; however, the basic customer service level is a good barometer of how well the companies are meeting their customers' immediate needs. The core causes and consequences of customer satisfaction are [7]:

- Customer-Perceived Quality

- Customer-Perceived Value

- Customer Perceived Expectations

- Customer Complaints and Customer Retention

- Customer Satisfaction Elasticity

The attitude and social behavior in customer services has the critical, decisive and significant role. Attitude has three components: cognitive (knowledge), affective (emotions), and conative (behavioral). Some of the most advanced thinking in the business world recognizes that customer relationships are best treated as assets, and that methodical analysis of these relationships can provide a road map for improving them. There are two types of customer service metrics, descriptive and functional. A descriptive metric indicates what the customer thinks about service, while a functional metric measures the occurrence of those events that we assume are responsible for customer satisfaction and loyalty. Besides, other important points considered as vital for measuring customer service are: Facilities (work setting, physical, resources etc.); Staff (liberty and empowerment); Communications; Internet Site; Complaint Handling Processes; Timeliness; and Printed Material.

In the field of telecommunication, customer service is often coupled with quality of service (QoS). As such, such telecommunication service providing companies (either wired or wireless) attach equal importance to service attributes of quality and value with its customer satisfaction.

The global agencies viz. ITU, FCC, GSM World Association etc. are of the view that customers should always be treated with courtesy and can expect the following standards of customer service when interacting 
with service proving company: Service providers (SPs) welcome customer comments on the quality of the service they provide, and on the performance as compared to the Customer Service Standards. The visiting/walk-in customers requesting SPs for information will be met with an informed and courteous staff that should be able to respond to their requests.

\subsection{CELL PHONE COMPANIES IN PAKISTAN: CUSTOMER SERVICE ECHELON}

The data in this research study is collected from two sections of samples: 180 customers (30 customers each of the 6 cellular services providers) and a focus group of 18 employees (3 managers and front-end staff directly dealing with customer desks from each cellular service provider). The objective behind collecting information from both the samples was to check how balanced customer service perceptions are at both ends.

A 10-item rating scale questionnaire was administered to the 180 customers. The items carried statements about overall customer satisfaction, ambience and comfort of the customer service center, ordering processes, complaints handling, and regularity of after sales support etc.

Responses were tabulated descriptively to results in 68\% customers claiming an overall satisfaction level with the quality of customer services at each service provider. On a statement of purchases, $80 \%$ customers preferred to buy new mobile connection from franchises or retail outlets. The tendency of visiting company's customer service centers, web site, and contacting call center calling was reported at a lower scale (23\%).

Some respondents however did show dissatisfaction regarding some technical factors ---- network constraints, and voice fades/breaks.

According to customer responses on service satisfaction, the companies are ranked below:

\begin{tabular}{|c|c|c|}
\hline Company & $\begin{array}{c}\text { Service Satisfaction } \\
\text { (in \% ages) }\end{array}$ & Ranking \\
\hline Warid & 73.2 & 1 \\
\hline Telenor & 71.7 & 2 \\
\hline Mobilink & 70.8 & 3 \\
\hline Ufone & 69.6 & 4 \\
\hline Paktel & 69.5 & 5 \\
\hline Instaphone & 69.1 & 6 \\
\hline
\end{tabular}

In terms of service satisfaction, the two newest cellular service providers, Warid and Telenor have taken a lead. The oldest, Paktel and Instaphone, are at the bottom, while Mobilink, the first GSM providers in Pakistan, is ranked at the $3^{\text {rd }}$ position.

Results of focus group interviews revealed that $75 \%$ sampled customer care staff of cell phone companies believes that their companies consider customer care as one of the key objectives. They also conduct regular surveys to determine customer needs. These staff regard 'poor attitude' a major source of dissatisfaction to customers.

Sampled customer service personals believe their CS front-end staff that is in direct interface with customers is skilled, duly trained, courteous, gregarious and friendly. Secondly the service providing staffs consider that their efforts in customer request process, delivery and support are adequately functioning with suitable arrangements.

The unanimous opinion from all sampled respondents (customers and CS staff) about point of customer service and satisfaction is more or less common i.e. it lies at modest level. The other positive factor evident from sampled CS staff response is the realization that the poor attitude, delay, and lean after sale support are the key sources of dissatisfaction. All cellular phone companies believe customer service as one of their key objectives; therefore it can be safely presumed that they will address weaknesses to escalate the level of satisfaction among customers

\subsection{CONCLUSION}

The survey results portrays certain evocative results; from customer's response it appears that customer service centers of cellular companies are physically well equipped and endowed with due comfort for the customers; however, the response regarding attitude of front-end staff is distressing. The time factor and commitment in order processing, and delivery and complaint handling needs to be improved. Customers seeking information expect swift and precise response. The survey reveals that verbal information is not being provided up to customers' preferences. The availability of printed material at point of sales pacifies this issue from further deterioration. Majority of customers are satisfied with service quality, nevertheless technical issues like poor signals, network constraints and faint voice are main concerns.

Rankings of the cellular companies show that customers and staff alike place all 6 within a range of $69-73 \%$. This proves that all six companies are competitive in service satisfaction, yet the 2 newest, Warid and Telenor have taken lead in these areas. This should sound some alarm bells with older companies, especially Mobilink, who is now places in the third rank. Companies with similar offerings can now only compete and be on top if they are able to value adding stronger customers' satisfaction. Perhaps, all service providers need to start thinking along the lines of 'customer care' than simply 'customer service'.

\section{REFERENCES}

[1] Manual on Statistics of International Trade in Services, UN (WTO), Geneva, Luxembourg, New York, Paris, Washington, D.C., 2002.

[2] Bushra Bhatti, “GSM Award-a success story”; Pakistan Observer, Saturday, February 25, 2006. 
[3] Martha Rogers, "Customer service tips from an expert"; The Daily Resource for Entrepreneurs Nov. 2000. [4] Schiffman, Bednall, Watson, and Kanuk. Consumer Behaviour; $2^{\text {nd }}$ Edition; Prentice-Hall, Australia 1997.

[5] Peter F. Drucker. The Practice of Management, Harper \& Row, Publishers Inc. 1954.

[6] Richard Normann. Service Management $3^{\text {rd }}$ Edition, John Wiley \& Sons limited 2000.

[7] Stephan M. Ross, "The American Customer Satisfaction Index (ASCI) at Ten Years”; Claes Fornell 2005. 